\title{
DISCURSO, COMPLEXIDADE E SUSTENTABILIDADE AMBIENTAL EM ORGANIZAÇÕES
}

\author{
J.R.T.Lima ${ }^{*}$, C.R.M.de Lima ${ }^{2}$ \\ 1 Universidade Federal de Alagoas. 57309005 - Arapiraca, AL - Brasil \\ 2 Instituto Brasileiro de Informação em Ciência e Tecnologia, IBICT. 22290160 - Rio de Janeiro, RJ - Brasil \\ *jrtlima@gmail.com
}

Artigo submetido em 12/08/2015 e aceito em 30/08/2015

\section{RESUMO}

Neste artigo busca-se realizar uma investigação sobre a dinâmica da internalização da sustentabilidade ambiental em uma organização produtiva do setor sucroenergético. A discussão teórica se desenvolve a partir da crítica de Jurgen Habermas ao funcionalismo sistêmico de Niklas Luhmann. Também, discute-se o tema esfera pública ambiental e administração da sustentabilidade ambiental, como forma de adequar as organizações aos novos padrões de qualidade exigidos e demandados pelo Estado, Mercado e Sociedade. Os procedimentos metodológicos utilizados foram: entrevista, análise de documentos e aplicação questionário fechado. $\mathrm{O}$ questionário usado com 12 representantes da usina possui trinta (30) assertivas, acompanhadas cada uma delas de dois cenários extremos. Os resultados apresentam que a organização passou a internalizar a sustentabilidade ambiental em seu sistema organizacional a partir de um Termo de Ajustamento de Conduta, elaborado pelo Ministério Pública Estadual. Assim como ao internalizar as práticas sustentáveis houve adaptação em diferentes áreas, como: gestão organizacional, aquisições, gestão da produção, gestão de pessoas e gestão de marketing.

PALAVRAS-CHAVE: Sustentabilidade ambiental, Administração da sustentabilidade, setor sucroenergético.

\section{DISCOURSE, COMPLEXITY AND SUSTAINABILITY AMBIENTAL IN ORGANIZATIONS}

\begin{abstract}
In this article we seek to conduct an investigation into the dynamics of internalization of environmental sustainability in a productive organization of the sugarcane industry. The theoretical discussion is developed from the criticism of Jurgen Habermas to systemic functionalism of Niklas Luhmann. Also, we discuss the theme environmental public sphere and administration of environmental sustainability as a way of adapting organizations to new quality standards required and demanded by the State, Market and Society. The methodological procedures used were: interviews,
\end{abstract}

document analysis and closed questionnaire application. The questionnaire used with 12 representatives of the plant has thirty (30) assertive, accompanied each of two extreme scenarios. The results show that the organization started to internalize environmental sustainability in their organizational system from a Conduct Adjustment Term, prepared by the Public Ministry State. As well as to internalize sustainable practices were adapted in different areas such as: organizational management, procurement, production management, people management and marketing management.

KEYWORDS: Environmental sustainability, sustainability management, sugarcane industry. 


\section{INTRODUÇÃO}

A questão da cultura canavieira está ligada ao processo de colonização brasileiro, sendo que isto pode ser percebido nos trabalhos de Holanda (1995), Freyre (1963), e no de Furtado (2004). Todos os autores mencionados mostram como a formação social e econômica do Brasil possui proximidades com o desenvolvimento da cultura da cana de açúcar.

A cultura canavieira, como ilustra Holanda (1995) e Freyre (1937), se desenvolveu no Brasil com preceitos capitalista e, desta forma, gerou inúmeros problemas para o ambiente natural. A racionalidade econômica que marcou a introdução do setor sucroenergético, foi marcante para que o desenvolvimento do setor, ao longo de sua história, gerasse um enorme passivo ambiental.

$\mathrm{Na}$ atualidade tem-se notado algumas modificações na postura que as organizações e entidades representantes (sindicatos e associações) do setor, vêm tomando com relação a sua produção e os impactos ambientais gerados. É a partir desta nova postura que o presente trabalho se desenvolve. O mesmo busca investigar a internalização da temática ambiental em uma organização do setor sucroenergético. A investigação busca analisar o momento de inserção da temática ambiental e as alterações que tal ocorrência provoca no interior da organização, ou seja, a dinâmica que a administração da sustentabilidade ambiental gera nos diversos setores (gestão organizacional, gestão de pessoas, gestão da produção, aquisições e equipamentos, saúde e segurança no trabalho e gestão de marketing) do ambiente investigado.

A opção teórica, que servirá de sustentação para o entendimento do caso empírico, busca desenvolver uma discussão entre Habermas e Luhmann, como forma de entender a relação entre sistema e ambiente. A partir deste ponto há a utilização da teoria de Niklas Luhmann sobre sistemas. O uso do Luhmann possibilita entender como são criados e como se desenvolvem os sistemas. Luhmann afirma que os sistemas são reduções da complexidade existente no ambiente, ou em termos habermasianos, do mundo da vida. A partir deste ponto Luhmann chega a uma teoria onde os sistemas são auto-referenciais, autopoiéticos e operacionalmente fechados.

Contudo, a redução acaba por limitar a percepção dos fatos existentes no ambiente externo aos sistemas. Esse fato decorre, tendo em vista, que a intersubjetividade, que era compartilhada por uma linguagem comum e fonte de integração, passa a ser substituída pela interação codificada entre os sistemas funcionais.

A substituição do compartilhamento de uma linguagem comum pela mediação codificada é a base para a crítica habermasiana à teoria de sistemas de Luhmann. Diante deste ponto destaca-se o conceito de esfera pública em Habermas. Tem-se a esfera pública como o ambiente no qual a sociedade civil expõe os problemas enfrentados na esfera privada e debate publicamente, gerando um entendimento sobre o tema debatido, ou seja, uma opinião pública.

Após a discussão teórica entre Habermas e Luhmann introduz-se à análise da discussão envolvendo a problemática ambiental vivenciada pela sociedade moderna, por meio da ideia de "esfera pública ambiental". A esfera pública ambiental pode ser compreendida como o local onde as demandas privadas, sobre a problemática ambiental, são debatidas.

A concepção de sustentabilidade ambiental, criada na esfera pública ambiental, acaba por desencadear em demandas para outros sistemas. Dentre os sistemas que devem responder a tais demandas estão as organizações empresariais.

A ideia de sustentabilidade ambiental é internalizada pelas organizações por meio da administração da sustentabilidade ambiental. Esta é entendida como a forma em que a organização desenvolve suas atividades visando melhorar o seu relacionamento com o ambiente natural (MAIMON, 1996). 


\section{REVISÃO BIBLIOGRÁFICA}

\subsection{As organizações como sistemas na Teoria de Niklas Luhmann}

A obra teórica de Niklas Luhmann devido a sua grande extensão, buscou analisar e propor mecanismos que possibilitassem a compreensão da sociedade moderna, principalmente no que tange a sua elevada diferenciação e dinâmica. Seus campos de análise foram os mais diversos, como política, legal, artes, economia, organizações dentre outros.

Seidl e Becker (2006b) destacam que a proposta teórica de Luhmann tem uma grande contribuição para a perspectiva organizacional. Os autores destacam que o ferramental teórico que constitui a teoria de sistemas de Luhmann acaba por lançar um novo olhar para as organizações e suas relações no ambiente no qual estão inseridas.

A teoria sistêmica de Niklas Luhmann realiza "uma operação de abstração que transpõe conceitos desenvolvidos em outros campos científicos - especialmente a biologia - para as ciências sociais e também através de uma profunda reflexão crítica sobre os diversos estágios por que passou a teoria dos sistemas nas últimas décadas" (FEDOZZI, 1997, p.21). A partir deste ponto Luhmann chega a uma teoria onde os sistemas são auto-referenciais, autopoiéticos e operacionalmente fechados.

A base da construção dos sistemas para Luhmann é a diferenciação, entre estes (sistemas) e o seu ambiente ou entorno. Ou seja, há uma diferença entre o sistema, que possui fronteiras e o ambiente que está situado fora da fronteira. O que promove essa diferença segundo Neves e Neves (2006) é o grau de complexidade existente entre estes dois fatores (sistema/ambiente).

De acordo com Kunzler (2004) o sistema, na concepção de Luhmann, é a tentativa de reduzir a complexidade existente na pluralidade do mundo da vida. Porém, tais mecanismos utilizados para reduzir esta complexidade se dão internamente, tendo em vista que os sistemas são auto-referenciais, autopoiéticos e fechados operacionalmente.

Tal espaço, o sistema, possui mecanismos que o auto-referenciam, ou seja, desenvolvem sua contigencialidade, "o sentido", visando limitar a complexidade existente no ambiente. O "sentido" funciona como uma identidade, ou melhor, indica a função a ser exercida pelo sistema.

Neves e Neves (2006) indicam que para Luhmann complexidade é a totalidade das possibilidades de acontecimentos, que podem ser derivadas das infinitas interações entre elementos (comunicações) também infinitos, que existem no ambiente.

A complexidade se dá pelo fato de que no ambiente, vários elementos podem assumir inúmeras possibilidades de relações, tendo em vista que não há nenhum fator ordenador e desta forma aumenta-se a improbabilidade de operacionalização (NEVES e NEVES, 2006).

Para propor certo nível de ordem e com isso possibilitar mecanismos de funcionamento, os sistemas aparecem como uma tentativa de redução da complexidade existente no ambiente, por meio do processo de seleção de possibilidades (KUNZLER, 2004).

O processo seletivo ocorre pelo fato de que o sistema não suporta internalizar toda a complexidade existente no ambiente, pois com isso deixaria de ser sistema. Diante disto há pressão para selecionar determinadas possibilidades. Neste processo de seleção o que os sistemas fazem são justamente importar complexidade para fazer frente a complexidade do ambiente, ou seja como o próprio Luhmann destaca: apenas a complexidade pode reduzir a complexidade (LUHMANN, 1995). 
O "sentido" é o operador das fronteiras, é o diferenciador do sistema e do ambiente. O "sentido" adotado pelo sistema é que irá ativar o processo de seleção, onde prescreve o que deve ou não fazer parte do sistema. Ele que irá referenciar determinado elemento, pois o mesmo elemento pode ter diferentes significados (LUHMANN, 1995).

Kunzler (2004) destaca que o sistema "deve simplificar a complexidade para conseguir se manter no ambiente. Ao mesmo tempo em que a complexidade do ambiente diminui, a sua aumenta internamente". Para Luhmann (1997c, p. 14) as organizações podem ser entendidas como um sistema social autopoiético que tem como base a decisão: "Los sistemas organizacionales son sistemas sociales constituídos por decisiones y que atan decisiones mutuamente entre si. El conteniedo teórico de esta afrimación resulta de um problema más general: el problema de la compleijad sistémica."

A partir deste ponto podemos perceber que o processo de decisão é chave para os sistemas organizacionais, pois é por meio dele em que o sistema irá se desenvolver, respondendo ou não as irritações do ambiente. Lembrando que o sistema interage com outros sistemas e no processo de interação são realizadas as comunicações, ou seja, as pontes de ligação entre os sistemas e seu ambiente.

Neste processo de interação os sistemas, por meio do seu processo comunicativo, acabam por tomar decisões sobre as comunicações realizadas. Tais decisões se referem ao fato que o processo comunicativo para a Luhmann se baseia em três elementos: informação, mensagem e compreensão (entendimento).

De acordo com Seidl e Becker (2006a) o entendimento é o ponto central no processo comunicativo da teoria luhmanniana. Diante disto temos que o entendimento que as organizações absorvem da interação com seu ambiente acaba por influenciar seu processo de decisão, até mesmo quando não se decide. As decisões são próprias comunicações, pois as mesmas acabam por gerar novas comunicações.

Seidl e Becker (2006b) apontam que há uma relação paradoxal no processo de decisão, pois ao selecionar as alternativas existentes no ambiente, o sistema seleciona novamente algumas alternativas já pré-selecionadas. Neste momento as alternativas que foram selecionadas comunicam também o que não foi.

É importante destacarmos que o processo de decisão e, consequentemente, entendimento das informações do ambiente, dependem do grau de entendimento do sistema sobre o conteúdo da informação. Por isso as regras de decisão influenciam diretamente o processo de tomada de decisão ou comunicação, assim como, as decisões anteriores.

Seidl e Becker (2006b) relatam "A decision takes previous decision as decision premisses, or, formulated the other way around: every decision serves as a decision premise for later decisions." O próprio Luhmann (1997c) destaca: “... se deja determinar el processo de selección consciente que se produce en lasorganizaciones por consideraciones de esse integra em la decisión la historicidade, la experiencia anterior de conflitos, la evaluacion de poder o la ambición previa."

Porém, os sistemas autopoiéticos, são sistemas autoreferenciais e autoprodutores de suas próprias decisões. Neste ponto percebemos que há um ponto problemático para o campo gerencial pois, diante das dinâmicas externas do entorno, a organização que não consegue realizar uma leitura, ou, em termos luhmanniano, entendimento das comunicações, acaba por correr o risco de desaparecer.

O próprio luhmann $(1997 \mathrm{c}$,$) aponta que o processo de planejamento se apresenta como uma$ forma de imunizar as organizações das irritações do ambiente. $\mathrm{O}$ ato de planejar é preparar o 
sistema para seu processo de decisão, visto que a autoreferencialidade do sistema implica que suas decisões são baseadas no seu entendimento das informações provenientes do ambiente. Porém, as organizações para fazerem frente a complexidade do seu ambiente importam essa complexidade e promovem um reordenamento da sua estrutura interna.

Esse processo de importação de complexidade pode ser interpretado como um processo inovativo, pois traz novas demandas para o sistema. Entretanto cabe destacar que as modificações são produções internas do sistema, pois os mesmos são autopoiéticos.

Luhmann(1997c) aponta esse fato: "entendemos bajo el término de innovación un processo de decisión contrainductivo, un processo de decisión que decide diferente a lo que era de esperar y así, cambia las expectativas".

Assim tem-se que o processo decisório deve ser alterado, tendo em vista a dinâmica que ocorre tanto no ambiente interno do sistema quanto o que está no seu entorno. A relação de importação da complexidade, por meio da alteração dos processos seletivos, decisórios, acaba por regenerar as organizações na sua trajetória social.

Neste ponto percebe-se que a importância do processo de entendimento para o processo comunicativo das organizações, tendo em vista, que sua evolução dependerá deste processo. O entendimento é a chave da mudança, pois os sistemas são autopoiéticos, ou seja, produzem as próprias mudanças.

Porém, o fechamento em si dos sistemas sofre fortes críticas, pois acaba por proporcionar incompreensões sobre o ambiente externo. Isso pode ser percebido nos problemas ambientais desencadeados pelas organizações produtivas. Diante disto iremos a seguir propor uma visão crítica do funcionalismo sistêmico luhmanniano a partir da perspectiva habermasiana.

\subsection{Crítica Habermasiana ao funcionalismo sistêmico}

Habermas (1992) em sua crítica a razão funcionalista destaca o conceito de mundo da vida. Para o autor o mundo da vida pode ser entendido como o lugar onde as "intersubjetividades" são compartilhadas.

O mundo da vida por possuir esse compartilhamento de subjetividades é plural e este fato o aproxima da realidade complexa vivida na sociedade. Tal fato deriva do compartilhamento de subjetividades que há nele. Essa pluralidade possibilitava uma maior compreensão dos fatos que ocorriam no mundo, pois os entendimentos privados eram compartilhados.

Porém com o desenvolvimento da sociedade ocidental e do capitalismo, criou-se um processo de diferenciação social. Essa diferenciação refletiu na criação de sistemas funcionalmente diferenciados. Ou seja, a pluralidade até então existente no mundo da vida é substituído pela subdivisão "cartesiana", ocasionando na criação de vários sistemas funcionalmente diferenciados que buscam representar a realidade complexa (HABERMAS, 1992).

Esse fato cria uma nova formação social em que há sistema/mundo da vida. Nessa reformulação o mundo da vida deixa de ser o local das totalidades e passa a ser o entorno/ambiente de um sistema, ou seja, aquilo que está externo ao sistema.

Essa mudança tem como fator a modificação nos processos comunicativos que integram os sujeitos no mundo da vida. Pois, ao invés de haver o compartilhamento da intersubjetividade, passase a operar a comunicação com codificadores, visando reduzir a complexidade do mundo da vida. Isso promove o "desacoplamento" sistema/mundo da vida (HABERMAS, 1992).

Entretanto, essa ruptura desencadeia inúmeros problemas, ou como Habermas (1992) destaca "patologias sociais", fato que decore da tentativa de fragmentação do mundo da vida em 
sistemas que tentam representar uma parte especifica do próprio mundo. Porém, ao tentar fragmentar, tem-se um distanciamento da realidade e isso possibilita a ocorrência de patologias, como os problemas ambientais.

Habermas (1997) crítica a teoria de sistemas pelo fato dela criar sistemas diferenciados que são fechados em si mesmo. Pois, conforme a teoria luhmanniana, os sistemas são auto-referentes, autopoiéticos e operacionalmente fechados.

Outro ponto estabelecido pela teoria de sistemas de Luhmann é que os sistemas apenas interagem de forma seletiva, ou seja, apenas processam informação que fazem parte do seu "sentido" e de acordo com a sua própria interpretação.

Tais concepções são espaços para a crítica de Habermas, pois essa forma de atuação é limitadora, uma vez que a seletividade dos sistemas faz criar um distanciamento da realidade complexa, causando problemas como os danos ambientais.

A incapacidade dos sistemas que deriva da sua forma de interação entre o sistema e o seu ambiente, resulta numa forma "codificada" de interação, uma vez que a linguagem comum, contida no compartilhamento intersubjetivo do mundo da vida, é substituída pelos mecanismos codificadores de interação, os "códigos binários".

Além disso, de acordo com Habermas (1997) “O entendimento fora de códigos específicos passa a ser tido como coisa ultrapassada. Isso equivale a afirmar que cada sistema perde a sensibilidade em relação aos custos que inflige a outros sistemas".

Esse fato da incapacidade de perceber os custos é importante para se entender a problemática ambiental que aflige a sociedade no século XX, porque o mundo da vida orgânico ou natural, onde se encontra os recursos naturais passa a ser degradado, tendo em vista tais fatos não serem passiveis de codificação pelos sistemas.

Porém, Habermas (1992) destaca que movimentos de contestação destes custos surgem como forma de combater o que ele chama de "colonização do mundo da vida". Ele destaca vários movimentos sociais, como: o movimento feminista, movimento anti-nuclear, movimento pacifista, entre outros.

Habermas (1992) dá ênfase ao movimento "verde" ou ecológico para contestar os problemas vividos pela sociedade moderna. E destaca que esta contestação é resultado dos problemas derivados dos danos causados pelo industrialismo que pode ser entendido por um sistema incapacitado de perceber os danos que gera a outros sistemas, como o ambiente natural Pode-se perceber esse fato na passagem:" [...] los efectos de la gran industria sobre el equilíbrio ecológico, la drástica disminución de los recursos naturales no-regenerables y la evolución demográfica plantean graves problemas sobre todo a lãs sociedades industrialmente desarolladas." (HABERMAS, 1992, p. 559).

Habermas (1992) afirma que os "desequilíbrios sistêmicos" se tornam em crise quando interfere nas atividades dos sistemas. Entretanto, os movimentos de contestação influenciam os sistemas, por meio das discussões realizadas na esfera pública. Tal local é o ambiente onde reestruturam-se as intersubjetividades perdidas pela introdução codificadora dos sistemas.

Habermas define da seguinte forma: "A esfera pública pode ser descrita como uma rede adequada para a comunicação de conteúdos, tomadas de posição e opiniões; nela os fluxos comunicacionais são filtrados e sintetizados a ponto de se condensarem em opiniões publicas enfeixadas em temas específicos. [...]" (HABERMAS, 1997). 
A discussão oriunda da esfera pública faz considerar um fato importante, ou seja, a opinião, que emerge com o processo discursivo, passa a mediar o poder público, fazendo tornar pública vontades, até então contidas em uma esfera privada (intimidade).

A esfera pública além de problematizar, possibilita gerar entendimento por parte dos participantes, da temática discutida. Assim, a esfera pública constitui principalmente uma estrutura comunicacional do agir orientada pelo entendimento, a qual tem a ver com o espaço social gerado no agir comunicativo (HABERMAS, 1997).

O agir comunicativo que Habermas se refere é o mecanismo pelo qual os participantes da esfera pública, chegam a um entendimento mutuo sobre o problema discutido e, desta forma, acabam compartilhando uma intersubjetividade. Para que haja o agir comunicativo, os participantes devem comporta-se cooperativamente, colocando-se como falantes e ouvintes, possibilitando desta forma ampliar o campo discursivo (HABERMAS, 1990).

Diante deste ponto percebe-se que a esfera pública é um ambiente no qual seus participantes discutem seus problemas e criam, a partir disto, uma opinião pública, ou melhor, um entendimento mútuo sobre o tema discutido.

Esse fato permite identificar como a questão dos problemas ambientais, sentidos pela esfera íntima dos atores afetados, passam a ser debatidas publicamente dando início a crítica a racionalidade econômica e desencadeando a busca por alternativas como a ideia da sustentabilidade. Porém, cabe destacar que a esfera pública permite uma maior aproximação com a realidade hipercomplexa, tendo em vista que a mesma é formada pela pluralidade, ou seja, por entes heterogêneos.

Essa heterogeneidade possibilita discutir e problematizar temas que os sistemas, fechados em si, não conseguem absorver. A maior sensibilidade aos "problemas", contida na esfera pública, ocorre pelo fato de que a mesma está ligada a vida privada.

A sociedade civil, ao sofrer diretamente com tais "efeitos negativos", consegue captá-los e identificá-los antes que os sistemas. Esse fato é evidente quando se discute os problemas ambientais, pois foi a partir da discussão pública do tema que uma nova concepção de interação foi proposta, ou seja, a discussão sobre o desenvolvimento sustentável.

Essa sensibilidade proporcionada pela esfera pública possibilita ampliar os campos discursivos chegando ao Estado. Por isso, a esfera pública, muitas vezes, funciona como "detector" e local para a denúncia de problemas. A partir deste ponto, entramos na discussão sobre a esfera pública que discute e problematiza os problemas ambientais, ou seja, a esfera pública ambiental.

\subsection{A esfera pública ambiental}

McCormick (1992) afirma sobre o movimento ambientalista que "[...] o movimento não começou num país para depois espalhar-se em outro; emergiu em lugares diferentes, em tempos diferentes e geralmente por motivos diferentes".

O mesmo autor destaca que o movimento teve início com os "naturalistas" que buscavam uma maior conservação da natureza, tendo em vista a percepção de que cada vez mais o ambiente natural, tinha sua área reduzida. Tais preocupações eram de caráter "estético" e vieram a ter um novo caráter, mais radical, a partir da década de 1960.

Leis (1999) se posiciona destacando que o novo cenário mundial, desencadeado pelas críticas ao modelo adotado na Modernidade, acaba por influenciar inúmeros campos da humanidade, como: sociedade, o Estado e o mercado (organizações). 
Alguns segmentos da sociedade iniciam um processo de reflexão sobre a relação entre a sociedade e o meio ambiente, onde inúmeras organizações (ONG's ambientalistas, feministas, entre outras) são formadas para contestar o modelo atual e reivindicar alternativas. Tais reivindicações chegam ao Estado que inicia um processo de internalização destas reivindicações e passa a adotar medidas por meio de políticas e legislações.

O mercado por se relacionar diretamente com estes outros segmentos (sociedade e Estado), além de perceber a relação entrópica do seu modelo de produção, acaba aderindo a ações de sustentabilidade, com vistas a manter a sua sustentabilidade econômica.

Diante deste fato passam (sociedade) a trazer as preocupações de sua esfera privada para o debate na esfera pública. Esse processo inicia um período em que cria-se uma "esfera pública ambiental", que é o local onde são discutidos os problemas socioambientais gerados pelas "irracionalidades" da racionalidade econômica.

Com o entendimento de que a sociedade corre "perigo" acaba-se por gerar uma opinião pública em que os problemas ambientais são percebidos. Essa sensibilização decorreu em demandas para outros setores da sociedade como o científico e o político.

O debate científico sobre a racionalidade econômica como propulsora da problemática enfrentada pela sociedade contemporânea só começou a fazer parte da discussão, por meio da introdução de cientistas sociais. O reflexo desta introdução foi a criação do Clube de Roma. (MCCORMICK, 1992; LEIS, 1999).

Esta associação fundada em 1968, tinha como objetivo pesquisar os componentes políticos, econômicos, naturais e sociais interdependentes do sistema global. Em 1972 lança um relatório intitulado de The Limiths of Growth (Limites do Crescimento).

O relatório apontava para o perigo da manutenção do modelo de crescimento econômico adotado. Há uma severa crítica à racionalidade econômica, que não reconhece os limites impostos pelo ambiente natural e social. O resultado das proposições foi a ideia de "crescimento zero", onde a economia deveria ser estagnada (MCCORMICK, 1992).

A publicação deste relatório foi realizada no mesmo ano em que houve a Conferência das Nações Unidas sobre o Meio Ambiente Humano. Ocorrida em Estocolmo, serviu para discutir, politicamente, as problemáticas enfrentadas pelo Meio Ambiente em decorrência dos efeitos negativos da racionalidade econômica (MCCORMICK, 1992).

Nos preparativos desta conferência, Sachs (2000) destaca que existiam duas correntes antagônicas: os que viam abundância de recursos (the cornucopians) e os "catastrofistas" ou "zeristas" (doomsayers).

Os primeiros, formado basicamente por países em desenvolvimento, acreditavam que os recursos naturais eram abundantes e as preocupações com o meio ambiente eram interpretadas como um fator inibidor de crescimento econômico. Para a segunda corrente estavam aqueles que acreditavam na exaustão dos recursos naturais devido ao crescimento demográfico e econômico, ou seja, as sociedades do mundo "desenvolvido", pois sentiam os efeitos primeiramente.

Esses antagonismos de visões marcaram o desenrolar da Conferência, onde os países do Sul reivindicavam seu crescimento econômico, tendo em vista os problemas sociais que possuíam. Eles acreditavam que o debate da problemática ambiental, mascarava uma preocupação econômica dos países do Norte. Os do Norte, sentido uma maior pressão de sua sociedade, queriam estagnar o crescimento. 
Segundo Mccormick (1992), a Conferência de Estocolmo foi o acontecimento que mais influiu na evolução do movimento ambientalista internacional. Houve uma ampliação do campo discursivo que deixou de ser limitado à proteção da natureza, para compreender que a problemática está localizada na forma errônea de como a humanidade se utiliza dos recursos naturais.

Outros fatos importantes decorrentes da Conferência foram a ampliação da esfera pública ambiental, pois " a conferência não somente colocou as ONGs nacionais em contato uma com as outras, mas enfatizou o fato de que enfrentavam problemas comuns que pediam uma resposta combinada" (MCCORMICK, 1992, p. 111).

Paralelamente às discussões da Conferência de Estocolmo, tinha-se o debate entre "crescer" e "não crescer". Diante deste fato surgiu, na década de 70 , uma tentativa conciliadora ou uma alternativa ao "caminho destrutivo", o ecodesenvolvimento.

A nova forma de propor o desenvolvimento tem como base a multidimensionalidade (social, ambiental, econômica, cultural e espacial), além do respeito às especificidades locais. A mesma assume uma postura de "filosofia do desenvolvimento", pois busca considerar variáveis que até então não eram incluídas no planejamento do desenvolvimento (SACHS, 2007).

Essa ideia elaborada primeiramente pelo Ecodesenvolvimento, de harmonização dos fatores de produção com as outras dimensões, possibilitou que um novo modelo de desenvolvimento econômico fosse pensado.

Isso se deu a partir da década de 1980, com o lançamento do relatório da Comissão Mundial sobre Meio Ambiente e Desenvolvimento (CMUMAD), onde o novo modelo de desenvolvimento ganhou a denominação de "Desenvolvimento Sustentável".

A definição desta nova forma de desenvolvimento é percebida como "aquele que atende às necessidades do presente sem comprometer a possibilidade de as gerações futuras atenderem a suas próprias necessidades" (CMUMAD, 1991).

Essa nova percepção de que a dimensão ambiental deve ser considerada, iniciada por meio das discussões nas esferas públicas ambientais, acabou por penetrar nas esferas privadas do campo político e do mercado. Viola (1996) destaca que o processo de globalização impôs essa nova postura ao governo brasileiro. Esse fato se concretiza na realização da Rio-92, em território brasileiro.

O novo posicionamento do Brasil deriva de uma postura política globalizada, onde o país, para elevar seu posicionamento na economia mundial e melhorar o diálogo no comércio internacional, atenta para as demandas dos países desenvolvidos, ou seja, a preocupação com o ambiente natural. Isso tem reflexo imediato na adoção e implementação de políticas ambientais (Viola, 1996).

A discussão sobre a sustentabilidade ambiental também influenciou na criação de barreiras "não-tarifárias" ou "barreiras verdes" para a comercialização de produtos no mercado internacional (YOUNG; LUSTOSA, 2001).

Estas modificações no mercado desencadearam em demandas para as organizações. De acordo com Leis (1999) a partir das décadas de 1980/90 o Desenvolvimento Sustentável foi adotado como modelo de gestão e atividade empresarial.

Um exemplo deste fato foi a criação do Conselho Empresarial para o Desenvolvimento Sustentável (BCSD), em 1990. O conselho elaborou um relatório "Mudando o Rumo" que propunha uma nova forma do empresariado aderir ao desenvolvimento sustentável, modificando, desta forma, a postura do mercado perante sua interação com o ambiente natural. 
Egri e Pinfield (1997) mostram que a degradação ambiental só se torna relevante para as organizações no momento em que interfere na sua performace. Isso mostra que a redução das fontes de inputs, como também modificações no mercado influenciam e solicitam adaptações das organizações para que as próprias possam manter-se ativas.

Além desta percepção, que a racionalidade é limitada e provoca a redução das próprias bases da reprodução capitalista, conforme já destacado por O'connor (1991) como uma contradição, há uma mudança nos consumidores, tem-se, por meio das discussões na esfera pública, a criação de uma opinião pública sobre os problemas ambientais e isto, reflete no surgimento dos "consumidores verdes".

Portilho (2004) define essa tipologia de consumidores da seguinte forma: "[...] aquele que, além da variável qualidade/preço, inclui em seu "poder de escolha", a variável ambiental, preferindo produtos que não agridam, ou são percebidos como não agredindo o meio ambiente".

Por fim, as discussões sobre a problemática ambiental realizadas numa esfera pública acabam por se disseminar em outros segmentos sociais, como o Estado e o mercado. Isso traz demandas para as esferas privadas destes sistemas e promove a exigência de uma nova postura das organizações empresariais.

Essa postura visa tornar seu modelo produtivo menos impactante para o ambiente natural, tendo em vista, o reconhecimento do poder autodestrutivo da manutenção do modelo anterior. Para tornar este fato prático desenvolve-se um modelo de produção que internalize as limitações do ambiente natural e desenvolva suas ações, tendo como base os preceitos da sustentabilidade ambiental.

\subsection{Administração da sustentabilidade ambiental nas organizações}

A internalização no ambiente privado das organizações, da sustentabilidade ambiental gera o que se denomina de administração da sustentabilidade ambiental (ASA). A mesma parte da necessidade de mudança da interação sistema produtivo versus ambiente natural.

De acordo com Maimon (1996) a criação da área de meio ambiente dentro do contexto organizacional é inicialmente atrelada ao sistema de produção. Posteriormente, essa nova função, passa a ser denominada de Gestão Ambiental ou ASA e passa fazer parte do contexto geral da organização. Para Epelbaum (2004) a ASA é percebida como um segmento da gestão empresarial que se preocupa com a identificação, avaliação, monitoramento, controle e redução dos impactos ambientais oriundos de suas atividades.

Araújo (2001) percebe a administração da sustentabilidade ambiental como "[...] um conjunto de medidas e procedimentos definidos e aplicados que visam reduzir e controlar os impactos introduzidos por um empreendimento sobre o meio ambiente". Dias (2006), por sua vez, aponta que "[..] é a gestão cujo objetivo é conseguir que os efeitos ambientais não ultrapassem a capacidade de carga do meio onde se encontra a organização, ou seja, obter-se um desenvolvimento sustentável”

De acordo com Epelbaum (2004), as organizações ao se verem pressionadas a dar respostas sobre as questões ambientais propuseram, inicialmente, a adoção de tecnologias end-of-pipe (fimde-linha). Estes mecanismos foram inicialmente utilizados para responder as legislações que demandaram novos padrões de qualidade ambiental.

Segundo Sanches (2000), esses mecanismos procuram combater apenas as saídas "indesejáveis" dos rejeitos produtivos, não interferindo no processo. Para esse mecanismo são 
utilizados equipamentos como: filtros, incineradores e estações de tratamento de efluentes (ETE). Contudo, com o passar dos anos notou-se que esse mecanismo era provedor de grandes custos tanto no processo de instalação quanto de manutenção, sem gerar nenhum valor agregado ao produto.

Com a tecnologia end-of-pipe adotada pelas organizações, os esforços ambientais apenas se concentravam no controle da poluição, acarretando aumento nos custos produtivos. Porém, surge uma nova visão que busca agir de forma preventiva ao invés de remediativa.

Para Porter e Van der Linde (1995), a poluição é encarada como desperdício econômico, daí a necessidade de se trabalhar a minimização deste subproduto enfatizando melhorias no processo produtivo. Outro fator determinante para esta mudança de foco, foi o surgimento da Total Quality Managment - TQM (Gestão da Qualidade Total).

O objetivo da TQM era a redução do desperdício, dos custos, controle de processos e melhorias das condições de trabalho. Valendo-se destes princípios surge o Total Quality Environmental Management - TQEM (Gerenciamento Total da Qualidade Ambiental) que fundamenta-se nos mesmos princípios da TQM (MARTINS e NASCIMENTO, 1998).

Nascimento, Lemos e Mello (2008) destacam que no ambiente interno da organização existem várias áreas que possuem funções específicas e que para a realização dos objetivos organizacionais devem estar interligados. Os mesmos autores afirmam que a implementação da administração da sustentabilidade ambiental acaba por interagir com todas essas áreas.

Quadro 1 - Setores organizacionais e interações da administração da sustentabilidade ambiental

\begin{tabular}{|c|l|}
\hline ÁREA SETOR & \multicolumn{1}{c|}{ FORMAS INTERAÇÃO } \\
\hline Alta direção & Aprovação e o apoio necessário para a implantação de ações sustentáveis \\
\hline Marketing & $\begin{array}{l}\text { Deve avaliar as reais necessidades dos consumidores, como também auxiliar no projeto } \\
\text { de produtos que reduzam os impactos no meio ambiente. }\end{array}$ \\
\hline $\begin{array}{c}\text { Pesquisa e } \\
\text { Desenvolvimento (P\&D) }\end{array}$ & $\begin{array}{l}\text { Desenvolver os processos de P\&D, tendo como base as ações de preservação ou redução } \\
\text { dos danos ambientais. }\end{array}$ \\
\hline Compras & $\begin{array}{l}\text { Avaliar o padrão de sustentabilidade das matérias-primas adotadas no sistema produtivo, } \\
\text { como também avaliar a sustentabilidade dos fornecedores. }\end{array}$ \\
\hline Produção & $\begin{array}{l}\text { Implantar processos produtivos que reduzam os impactos no meio ambiente. Essas ações } \\
\text { podem ser por meio das práticas end-of-pipe ou de prevenção da poluição. }\end{array}$ \\
\hline Finanças & $\begin{array}{l}\text { Avaliar os investimentos, as receitas e as despesas que estão ligadas a implantação e } \\
\text { execução da gestão ambiental. Outro ponto relacionado a finanças é a contabilidade } \\
\text { ambiental que busca contabilizar a parte financeira condizente com a área ambiental, e } \\
\text { também o balanço socioambiental que demonstra as práticas sociais e ambientais geradas } \\
\text { pela organização no desenvolvimento da gestão ambiental }\end{array}$ \\
\hline Recursos Humanos & $\begin{array}{l}\text { Responsável pela capacitação e formação da consciência ambiental nos funcionários da } \\
\text { organização. Tem grande importância no fato de que para a realização efetiva de uma } \\
\text { gestão ambiental, as pessoas que fazem a organização devem estar integradas às } \\
\text { filosofias e os objetivos que a nova forma de gestão preconiza. }\end{array}$ \\
\hline
\end{tabular}

Fonte: Nascimento, Lemos e Mello (2008)

Os mecanismos adotados para a prática da administração da sustentabilidade ambiental resultam em desafios para as organizações empresariais.

Os desafios organizacionais podem ser interpretados sobre três correntes: as legislações que o Estado impõe; o mercado que demanda produtos com qualidade ambiental; e o próprio sistema produtivo que deve se reestruturar, minimizando a ação entrópica dos impactos ambientais decorrentes da atividade. Diante deste fato, nota-se que devem ocorrer alterações nas estruturas organizacionais para reduzir os impactos que as atividades organizacionais promovem. 


\section{MATERIAIS E MÉTODOS}

Para que os objetivos propostos neste trabalho fossem alcançados realizou-se uma pesquisa cuja natureza é exploratória.

O trabalho de campo visa à coleta de dados empíricos sobre a administração da sustentabilidade ambiental na usina investigada combinando os seguintes procedimentos: análise documental; e entrevistas com funcionários, usando questionário estruturado;

O questionário usado nas entrevistas com os representantes da usina possui trinta (30) assertivas, acompanhadas cada uma delas de dois cenários extremos. As assertivas focam em aspectos pertinentes para a investigação das relações da administração da sustentabilidade ambiental no interior da organização.

Cada assertiva é respondida em escala Likert, em que a nota mais baixa equivale à relação incipiente e a mais alta a relação forte. As que recebem nota baixa caracterizam uma deficiência, enquanto que as notas altas apontam para aspectos positivos na organização. São apresentados dois cenários explicativos para cada assertiva, sendo um péssimo (cenário 1) e o outro ótimo (cenário 5). Caso a situação da organização se enquadre mais no cenário péssimo, a nota deverá ser mais próxima de 1 . Se a organização apresenta mais características do cenário ótimo, a nota deverá ser mais próxima de 5 .

Os participantes entrevistados foram num total de 12 (doze) integrantes das diversas áreas da organização, como: setor agrícola, industrial e administrativo. As respostas possibilitaram visualizar a realidade da administração da sustentabilidade ambiental na organização e suas interações entre os diversos setores organizacionais. Além das respostas obtidas no questionário, houve uma discussão, individualizada, com os participantes sobre as respostas. Esse mecanismo visou obter uma maior quantidade de informações. Essa parte foi gravada e utilizada para evidenciar as respostas obtidas.

Para facilitar a visualização dos dados, as perguntas foram agrupas em 6 categorias de análise. São elas: gestão organizacional, gestão de pessoas, gestão da produção, aquisições e equipamentos, saúde e segurança no trabalho e gestão de marketing.

\section{RESULTADOS E DISCUSSÃO}

\subsection{A variável sustentabilidade introduzida nas preocupações organizacionais}

A organização estudada está localizada no estado de Alagoas. Além disso possui filiais no estado de Minas Gerais. A mesma faz parte do setor sucroenergético, que sempre teve um papel de destaque na economia estadual, assim como foi o responsável por inúmeros danos ambientais e sociais. A usina estudada tem, em seu ambiente organizacional, um setor que busca desenvolver ações na administração da sustentabilidade ambiental. Contudo, no decorrer de sua história, a interação com o ambiente natural nem sempre foi marcada por tamanha preocupação, ao ponto da organização internalizar a questão ambiental e estruturar um setor para gerir a sustentabilidade ambiental nas suas atividades.

Antes da criação do setor de meio ambiente, as ações eram restritas às áreas agrícolas e industriais, sem grandes disseminações nas outras áreas da organização. As ações eram restritas à preservação de matas nativas, pela exigência das Reservas Legais, contida no Código Florestal Lei 12.651/2012. Outras ações eram a utilização dos subprodutos do sistema industrial, como vinhaça e bagaço, para adubação do solo, com perspectivas de redução dos custos produtivos.

O gerente Agrícola assinala que a "A questão ambiental não era disseminada para todos os funcionários da organização, ela era restrita ao setor agrícola, principalmente a área de irrigação". O 
responsável pela gestão ambiental da usina destaca que a variável sustentabilidade introduzida nas preocupações organizacionais, deriva da visão futurista do dono com as demandas que o mercado iria requerer:

[...] O fundador da empresa, sempre teve uma visão de futuro [..] a questão ambiental sempre foi uma prerrogativa dele, ele sempre esteve preocupado com isso[...] Nos aqui sempre somos visitados, são pessoas da França, do Japão, da Inglaterra, da China[...] Eles (compradores) sempre procuram saber como são as ações ambientais e sociais que desenvolvemos" (Coordenador de Gestão Ambiental).

Para os parceiros que são europeus, a primeira coisa que eles procuram olhar é a parte ambiental e social[...] a certificação já ajuda no momento de mostrar que possuímos ações de gestão ambiental (gerente agrícola da Usina)

Esse comentário evidencia a atuação do mercado externo, mais restritivo quanto a qualidade ambiental do produto, sobre a organização sucroenergéticas na adoção de novos padrões ambientais. Tal fato vem tendo maior ênfase na atual conjuntura com as demandas sobre o etanol, principalmente pelo mercado europeu. Entretanto, essa preocupação aumentou, segundo relatos do gerente agrícola, responsável pela irrigação, com a infração legal, ocorrida no ano de 2000.

A usina ao desenvolver seu processo de irrigação em uma Área de Preservação Permanente (APP), acabou por infringir o Código Florestal, pois seu sistema de irrigação não possuía licenciamento ambiental. Esse fato desencadeou a abertura de processo pelo órgão de meio ambiente estadual.

\begin{abstract}
Havia um desconhecimento da legislação, como também ninguém aplicava. O IMA/AL que era Instituto do Meio Ambiente aqui de Alagoas não era muito participativo. Nós fazíamos os projetos de irrigação e não tinha outorga nem licença. Porém, teve um dia em que fizemos um projeto de irrigação em uma APP. Ai... eu fui chamado para comparecer ao IMA/AL em 24 horas, para dar explicações sobre a infração. A partir daí tivemos que parar o projeto e retirar todos os equipamentos do local. (gerente agrícola da Usina)
\end{abstract}

O relato do engenheiro demonstra que o órgão sempre foi pouco participativo e com isso a usina, por não ter esta exigência, não apresentava tal preocupação.

O órgão fiscalizador, IMA/AL, até então ausente, notificou, por meio de auto de infração a usina e suspendeu o desenvolvimento do projeto de irrigação. Por meio desta ocorrência o órgão ambiental, em conjunto com o Ministério público estadual elaborou-se um TAC (Termo de Ajustamento de Conduta), em que a usina deveria desenvolver ações para compensar os danos ambientais causados por sua atividade, conforme define a Lei de Ação Civil Pública no 7347/85.

Outro ponto de destaque levantando pelo engenheiro, foi o fato de que a população residente no local afetado foi contra o projeto: “A população foi contra, pois eles não tinham benefício nenhum, diziam que a água acabaria, o rio iria secar" (gerente agrícola).

O relato mostra que a população tinha preocupação com o corpo hidrográfico do qual retirava sua sobrevivência, tendo em vista que eram pescadores. E que a preocupação aumentava em decorrência da implantação de um sistema de irrigação que não considerava os requisitos ambientais legais, tendo em vista que não possuía licença ambiental.

A partir deste ponto, por meio da atuação de um agente externo como o Estado, utilizandose das normas referentes à qualidade ambiental, a usina iniciou um processo de internalização da variável meio ambiente para o desenvolvimento de suas atividades, conforme destaca:

A partir deste ponto notamos que estávamos "ambientalmente" desorganizados. Começamos a solicitar todas as licenças ambientais. E o departamento de gestão ambiental foi criado para poder facilitar a organização e possibilitar desenvolvermos uma gestão do meio ambiente eficaz (gerente agrícola) 
A partir deste ponto, com a noção de que tal variável ambiental era importante tanto para o cumprimento legal, quanto para a imagem organizacional, a usina buscou criar um setor que trata de temática ambiental. Esse fato proporcionou o surgimento do setor de Gestão Ambiental na usina.

Para implantar a administração da sustentabilidade ambiental, a usina optou pelo modelo da ISO 14001, que define as diretrizes básicas para um Sistema de Gestão Ambiental - SGA. Esse sistema possibilitou a usina adequar suas atividades aos padrões de qualidade ambiental. O processo de criação do setor teve início no ano 2002 e teve o auxílio de uma empresa de consultoria.

A implantação se deu por meio da divisão da organização em três áreas; administrativa, agrícola e industrial, onde foram inicialmente envolvidos os gerentes de cada setor, os coordenadores e supervisores. Esta iniciativa, segundo o gestor ambiental, se deu na busca de integrar os líderes à nova "cultura" que a organização iria desenvolver. Em seguida foram englobados todos os funcionários com o programa de conscientização ambiental.

Para que o sistema pudesse ser implantado, foram realizados investimentos em torno de $\mathrm{R} \$$ 36.000.000,00 (trinta e seis milhões de reais). Tais recursos foram aplicados para a adaptação das instalações, treinamento de pessoal, recuperação de vegetação, entre outros. Em 2003 a empresa teve seu SGA certificado, atestando que os requisitos exigidos pela norma ISO 14001 foram atingidos. A partir deste ponto a empresa obteve um selo que possibilitou comprovar que há um sistema que auxilia na administração da sustentabilidade ambiental.

O setor de meio ambiente é descrito como um órgão de staff que assessora os três setores da organização (administrativo, industrial e agrícola) e está ligada à alta direção: "Ela fica como uma célula que serve aos três gerentes das áreas administrativa, industrial e agrícola. Ela assume um papel, por exemplo, de staff dentro da empresa e está diretamente ligada à alta diretoria" (Coordenador de Gestão Ambiental). O funcionamento do setor de meio ambiente ocorre por meio de encontros mensais com os setores da organização para a discussão das questões ambientais. Nesses encontros são discutidas as ações ambientais que cada setor desenvolve, cabendo aos gestores ambientais cobrar aos responsáveis das áreas o cumprimento dos objetivos e metas estabelecidos.

Desta forma, cada área da Usina possui sua responsabilidade pela manutenção e cumprimento da das ações ambientais. $\mathrm{O}$ setor de gestão ambiental possui uma função de integrar e coordenar essas ações, além de fiscalizar o cumprimento da política ambiental, por parte dos outros setores da organização. Os entrevistados destacam que a administração da sustentabilidade ambiental é importante e traz benefícios para a organização. Tanto os custos produtivos quanto a imagem da organização se beneficiam das ações desenvolvidas.

Atualmente temos uma boa relação com os órgãos ambientais. Eles nos olham com outros olhos, pois sabem o que nós estamos fazendo. A comunidade também aceita mais o nosso trabalho, eles participam de ações ambientais que nós realizamos. (Coordenador de Gestão Ambiental).

Estes fatos evidenciam que a organização obtém benefícios com a prática da administração da sustentabilidade ambiental, e estes benefícios não se limitam a redução de custos, pois possibilitam a abertura de mercados, além de melhorar a interação com a comunidade e órgãos ambientais.

\subsection{A dinâmica da sustentabilidade ambiental na usina}

A seguir será demonstrado como a internalização da administração da sustentabilidade ambiental se desenvolve na estruturação organizacional a partir da interação com diversos setores. 
As assertivas, apresentadas no quadro 2, demonstram as articulações que a internalização da gestão ambiental acaba por influenciar na gestão da organização. Esse fato envolve a preocupação de exercer controles sobre as atividades da empresa, buscando identificar se há mecanismos que possibilitem a organização avaliar suas atividades e propor controles, objetivando minimizar os impactos ambientais derivados das atividades.

\section{Quadro 2 - Gestão Organizacional}

\begin{tabular}{|c|c|c|c|c|c|c|c|}
\hline ASSERTIVA & CENÁRIO 1 & CENÁRIO 5 & 1 & 2 & 3 & 4 & 5 \\
\hline 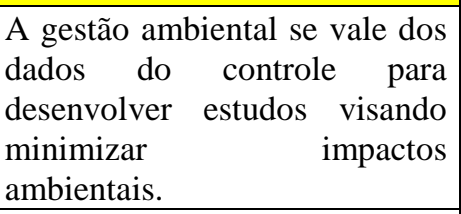 & $\begin{array}{l}\text { Não há avaliação da produção, } \\
\text { por meio de indicadores, visando } \\
\text { minimizar as falhas para reduzir } \\
\text { os desperdícios ou impactos } \\
\text { ambientais. }\end{array}$ & $\begin{array}{l}\text { Há avaliação da produção, } \\
\text { por meio de indicadores, } \\
\text { visando minimizar as falhas } \\
\text { para reduzir os desperdícios } \\
\text { ou impactos ambientais }\end{array}$ & & & & 2 & 10 \\
\hline $\begin{array}{l}\text { A análise e a minimização de } \\
\text { potenciais impactos ambientais } \\
\text { são sistematicamente realizadas } \\
\text { por indicadores e monitorados } \\
\text { pelos gestores. }\end{array}$ & $\begin{array}{l}\text { Os sistemas de informação não } \\
\text { informam com a confiabilidade } \\
\text { dados sobre a gestão ambiental } \\
\text { da organização. }\end{array}$ & $\begin{array}{l}\text { Os sistemas de informação } \\
\text { informam com } \\
\text { confiabilidade dados sobre } \\
\text { a gestão ambiental da } \\
\text { organização. }\end{array}$ & & & 1 & 5 & 6 \\
\hline 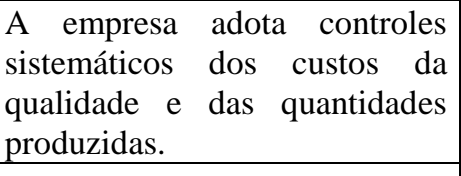 & $\begin{array}{l}\text { NÂO há controle de custos, } \\
\text { qualidade e das quantidades } \\
\text { produzidas }\end{array}$ & $\begin{array}{l}\text { Há um "sistema" que } \\
\text { controla os } \quad \text { custos, } \\
\text { qualidade e as quantidades } \\
\text { produzidas }\end{array}$ & & & & 2 & 10 \\
\hline $\begin{array}{l}\text { A gestão ambiental excede a } \\
\text { legislação ambiental. }\end{array}$ & $\begin{array}{l}\text { As ações da gestão ambiental são } \\
\text { apenas para dar cumprimento aos } \\
\text { requisitos legais. }\end{array}$ & $\begin{array}{l}\text { As ações da gestão } \\
\text { ambiental são realizadas } \\
\text { tendo em vista ao } \\
\text { desenvolvimento } \\
\text { sustentável. }\end{array}$ & & & & 3 & 9 \\
\hline $\begin{array}{l}\text { Os controles adotados pela } \\
\text { organização geram feedback e } \\
\text { resultam constantemente em } \\
\text { melhorias e avanços na } \\
\text { qualidade dos produtos } \\
\text { produzidos e nos processos. }\end{array}$ & $\begin{array}{l}\text { Não é realizado Feedback } \\
\text { visando melhorias e avanços na } \\
\text { qualidade }\end{array}$ & \begin{tabular}{llr} 
Feito os & \multicolumn{2}{c}{ controles } \\
realizado um \\
visando feedback \\
avanços na qualidade
\end{tabular} & & & 1 & 5 & 6 \\
\hline $\begin{array}{l}\text { Os investimentos são feitos } \\
\text { sempre levando em conta a } \\
\text { gestão eficiente do meio } \\
\text { ambiente. }\end{array}$ & $\begin{array}{c}\text { Os investimentos em meio } \\
\text { ambiente são realizados apenas } \\
\text { para adequação a legislações } \\
\text { pertinentes a atividade da } \\
\text { organização. }\end{array}$ & $\begin{array}{l}\text { Os investimentos em meio } \\
\text { ambiente são realizados } \\
\text { para melhorar a qualidade } \\
\text { ambiental e não apenas a } \\
\text { adequação a legislação. }\end{array}$ & & & & 3 & 9 \\
\hline
\end{tabular}

Segundo relatos dos entrevistados, seguindo os requisitos estabelecidos pela ISO 14001, a organização deve sempre estar reavaliando seus processos, buscando a melhoria contínua. Faz parte deste processo "reuniões críticas", onde são avaliadas as ações que foram desenvolvidas durante o ciclo de um ano.

Temos que avaliar nossas atividades, pois a norma (ISO 14001) exige que saibamos quais são nossos principais aspectos ambientais e a partir disto estruturamos medidas para evitar os impactos ambientais. O sistema tem isso como requisito primordial (Entrevistado 1).

As assertivas no quadro 3 possibilitam notar que se tem, como uma forma de desenvolver a administração da sustentabilidade ambiental, a preocupação em adquirir equipamentos que possibilitem menores impactos no ambiente natural. Um exemplo deste fato é a aquisição de filtros que possibilitam reduzir a emissão de poluentes gerados nas "caldeiras". 


\begin{tabular}{|c|c|c|c|c|c|c|c|}
\hline \multicolumn{8}{|c|}{ Quadro 3 - Aquisições e Equipamentos } \\
\hline ASSERTIVA & CENÁRIO 1 & CENÁRIO 5 & 1 & 2 & 3 & 4 & 5 \\
\hline $\begin{array}{lrrr}\text { Na aquisição } & \text { de } & \text { novos } \\
\text { equipamentos, a empresa } & \text { sempre } \\
\text { prioriza a } & \text { instalação } & \text { de } \\
\text { equipamentos menos poluentes. }\end{array}$ & $\begin{array}{l}\text { A compra não leva em } \\
\text { consideração equipamentos } \\
\text { menos poluentes. }\end{array}$ & $\begin{array}{l}\text { A aquisição } \quad \text { de } \\
\text { equipamentos menos } \\
\text { poluentes está impregnada } \\
\text { na cultura da empresa. }\end{array}$ & & & & 6 & 6 \\
\hline $\begin{array}{l}\text { A empresa busca constantemente a } \\
\text { modernização tecnológica como } \\
\text { forma de implementar melhorias no } \\
\text { sistema de produção da fábrica, } \\
\text { refletindo positivamente na } \\
\text { qualidade dos produtos. }\end{array}$ & $\begin{array}{l}\text { O comportamento quanto à } \\
\text { tecnologia é reativo; não } \\
\text { nota-se melhoria na qualidade } \\
\text { dos produtos e não raro a } \\
\text { empresa fica atrás dos } \\
\text { concorrentes. }\end{array}$ & $\begin{array}{l}\text { Há uma procura obstinada } \\
\text { por um lugar de vanguarda } \\
\text { em tecnologia. Havendo } \\
\text { investimentos em } \\
\text { processos, equipamentos, } \\
\text { instalações, pessoal, com } \\
\text { nítidas repercussões sobre a } \\
\text { qualidade. }\end{array}$ & & & 1 & 5 & 6 \\
\hline $\begin{array}{l}\text { Percebe-se que o incremento em } \\
\text { equipamentos e novas tecnologias } \\
\text { para minimização dos impactos } \\
\text { ambientais têm influência positiva } \\
\text { na qualidade e seus resultados. }\end{array}$ & $\begin{array}{l}\text { Não há indicadores que } \\
\text { correlacione os efeitos das } \\
\text { alterações na } \text { gestão } \\
\text { ambiental com a qualidade } \\
\text { produtiva }\end{array}$ & $\begin{array}{l}\text { Há indicadores } \\
\text { correlacionam os } \text { que } \\
\text { das alterações na gestão } \\
\text { ambiental com a qualidade } \\
\text { produtiva }\end{array}$ & & & & 4 & 8 \\
\hline $\begin{array}{l}\text { Os equipamentos e sistemas de } \\
\text { informação adotados permitem um } \\
\text { eficiente controle de todo o sistema } \\
\text { de produção da empresa. }\end{array}$ & $\begin{array}{l}\text { Não há investimento em } \\
\text { sistemas de informação }\end{array}$ & $\begin{array}{l}\text { O sistema de informação de } \\
\text { controle da produção é } \\
\text { funcional e recebe } \\
\text { investimentos de melhoria }\end{array}$ & & & & 5 & 7 \\
\hline
\end{tabular}

Além deste ponto há uma preocupação com a adequação dos fornecedores aos padrões ambientais estabelecidos pela organização. A depender do tipo de fornecimento documentações (licenças ambientas, certificação dentre outras) que atestam o atendimento aos requisitos legais são exigidas. As assertivas no quadro 4 possibilitaram inferir que administração da sustentabilidade ambiental interferiu, positivamente, na qualidade das condições de trabalho, resultando em menor número de acidentes, como também, na disseminação de um processo investigativo que visa prevenir futuros acidentes. A fala de um dos entrevistados demonstra bem a situação.

Quadro 4 - Segurança e Saúde Ocupacional

\begin{tabular}{|c|c|c|c|c|c|c|c|}
\hline ASSERTIVA & CENÁRIO 1 & CENÁRIO 5 & 1 & 2 & 3 & 4 & 5 \\
\hline $\begin{array}{l}\text { A organização vem acompanhando a } \\
\text { evolução dos conceitos ambientais, } \\
\text { aplicando-os à melhoria das condições de } \\
\text { trabalho, com o enfoque na saúde e } \\
\text { segurança ocupacional. }\end{array}$ & $\begin{array}{l}\text { A filosofia de melhoria } \\
\text { contínua na gestão ambiental } \\
\text { não está presente na cultura } \\
\text { da empresa. }\end{array}$ & $\begin{array}{l}\text { A filosofia de melhoria } \\
\text { contínua na gestão } \\
\text { ambiental está fortemente } \\
\text { aplicada na cultura da } \\
\text { empresa. }\end{array}$ & & & & 5 & 7 \\
\hline $\begin{array}{l}\text { Há uma sensível redução do número de } \\
\text { acidentes do trabalho associados aos } \\
\text { incrementos de novas tecnologias } \\
\text { adotadas. }\end{array}$ & $\begin{array}{l}\text { As novas tecnologias } \\
\text { adotadas não contribui no } \\
\text { controle ou diminuição de } \\
\text { acidentes de trabalho. }\end{array}$ & $\begin{array}{l}\text { As novas tecnologias } \\
\text { adotadas cooperam } \\
\text { substancialmente no } \\
\text { controle ou diminuição de } \\
\text { acidentes de trabalho. }\end{array}$ & & & 1 & 5 & 6 \\
\hline $\begin{array}{l}\text { A estrutura da empresa é segura e } \\
\text { ajustada para investigar e minimizar as } \\
\text { consequências de pequenos incidentes } \\
\text { com vistas à prevenção de potenciais } \\
\text { acidentes causadores de danos } \\
\text { ambientais. }\end{array}$ & $\begin{array}{l}\text { Apenas acidentes claramente } \\
\text { caracterizados são } \\
\text { considerados; incidentes são } \\
\text { ignorados, afinal, "há coisas } \\
\text { mais importantes para fazer" }\end{array}$ & $\begin{array}{l}\text { Quaisquer perturbações } \\
\text { são motivo de } \\
\text { consideração e análise; há } \\
\text { consciência de que nada } \\
\text { deve ser tolerado. }\end{array}$ & & & 1 & 1 & 10 \\
\hline
\end{tabular}

Além dos dados, os relatos dos entrevistados demonstram tão fato:

As coisas estão interligadas (gestão ambiental e saúde e segurança do trabalhador), e acabam se influenciado. Os cuidados com o meio ambiente reduzem os acidentes, pois o 
próprio treinamento, ao qual os funcionários são obrigados a fazer, para evitar acidentes ambientais, também influenciam no momento de evitar acidentes de trabalho (Entrevistado 4).

As assertivas, no quadro 5, que versam sobre a força de trabalho, possibilitam entender que a organização tem uma preocupação em desenvolver uma sistemática de treinamento, visando reduzir os riscos de danos ambientais, assim como melhorar o seu desempenho ambiental. Esse fato tem uma peculiaridade na usina, tendo em vista que há uma variação no quadro funcional, devido a sazonalidade da colheita da cana.

Quadro 5 - Gestão de Pessoas (treinamento, sensibilização e cultura organizacional)

\begin{tabular}{|c|c|c|c|c|c|c|c|}
\hline ASSERTIVA & CENÁRIO 1 & CENÁRIO 5 & 1 & 2 & 3 & 4 & 5 \\
\hline \begin{tabular}{lrr}
\multicolumn{3}{l}{ Existem planos de treinamento dos } \\
envolvidos nos & processos \\
produtivos & para & melhor \\
entendimento & das & práticas \\
realizadas e estes com os objetivos \\
organizacionais.
\end{tabular} & $\begin{array}{l}\text { Não há treinamentos periódicos } \\
\text { de conscientização para a } \\
\text { execução das atividades. A } \\
\text { empresa não tem esta } \\
\text { preocupação. }\end{array}$ & $\begin{array}{l}\text { Existes } r \text { treinamentos } \\
\text { periódicos de conscientização } \\
\text { para a execução das } \\
\text { atividades de maneira a } \\
\text { garantir a mínima qualidade } \\
\text { de saúde ocupacional. }\end{array}$ & & & 1 & 3 & 8 \\
\hline $\begin{array}{l}\text { Os padrões de qualidade adotados } \\
\text { estão impregnados na identidade } \\
\text { da organização (missão, visão, } \\
\text { valores e objetivos), e a qualidade } \\
\text { é uma prática e um compromisso } \\
\text { de todos os empregados. }\end{array}$ & $\begin{array}{l}\text { Não existe uma preocupação } \\
\text { clara com a qualidade na } \\
\text { identidade, o que reflete na } \\
\text { Cultura e no comportamento } \\
\text { dos funcionários. }\end{array}$ & $\begin{array}{l}\text { A qualidade é facilmente } \\
\text { identificada na identidade e } \\
\text { impregnada na Cultura e no } \\
\text { comportamento dos } \\
\text { funcionários. }\end{array}$ & & & 1 & 3 & 8 \\
\hline $\begin{array}{l}\text { Ocorre o envolvimento dos } \\
\text { funcionários para a implementação } \\
\text { de medidas de desempenho } \\
\text { visando melhorias no sistema de } \\
\text { produção. }\end{array}$ & $\begin{array}{l}\text { Não é prática da cultura da } \\
\text { empresa a participação dos } \\
\text { funcionários na implementação } \\
\text { de medidas de desempenho. }\end{array}$ & $\begin{array}{l}\text { Está inserida na cultura da } \\
\text { empresa a participação dos } \\
\text { funcionários } \\
\text { implementação de medidas } \\
\text { de desempenho. }\end{array}$ & & & 2 & 3 & 7 \\
\hline $\begin{array}{l}\text { A empresa investe continuamente } \\
\text { na capacitação de seus } \\
\text { funcionários para prover melhoria } \\
\text { da qualidade dos produtos. }\end{array}$ & $\begin{array}{l}\text { Não há investimentos em } \\
\text { treinamento que infere a } \\
\text { qualidade do produto. }\end{array}$ & $\begin{array}{llr}\text { Há investimentos } & \text { em } \\
\text { treinamento } & \text { para garantir } \\
\text { qualidade } & \text { satisfatória do } \\
\text { produto } & & \end{array}$ & & & & 8 & 4 \\
\hline $\begin{array}{l}\text { A análise e a minimização de } \\
\text { potenciais impactos ambientais } \\
\text { estão culturalmente difundidas. }\end{array}$ & $\begin{array}{l}\text { Não há por parte dos } \\
\text { funcionários preocupações com } \\
\text { a variável ambiental dentro da } \\
\text { organização. }\end{array}$ & $\begin{array}{l}\text { Há por parte dos funcionários } \\
\text { preocupações com a variável } \\
\text { ambiental dentro da } \\
\text { organização }\end{array}$ & & & & 1 & 11 \\
\hline $\begin{array}{l}\text { Os funcionários são capacitados } \\
\text { para evitar ao máximo ações } \\
\text { prejuduciais ao meio ambiente, } \\
\text { beneficiando a própria saúde dos } \\
\text { funcionários e moradores do } \\
\text { entorno. }\end{array}$ & $\begin{array}{l}\text { Não existem treinamentos para } \\
\text { a questão ambiental focado na } \\
\text { própria saúde dos funcionários } \\
\text { e moradores da região. Erros de } \\
\text { produção são constantes e é } \\
\text { inevitável a agressão ao } \\
\text { ambiente. }\end{array}$ & $\begin{array}{l}\text { Há treinamentos constantes } \\
\text { na questão ambiental, } \\
\text { focando na própria saúde dos } \\
\text { funcionários e moradores da } \\
\text { região. }\end{array}$ & & & & 5 & 7 \\
\hline
\end{tabular}

Além dos dados, os relatos dos entrevistados demonstram tão fato:

Nossos funcionários passam por treinamentos periódicos de reciclagem. Além disso, existem as ITs (instruções de trabalho) que descrimina as atividades a serem desenvolvidas.[...] para o cumprimento das instruções deve ter um forte treinamento, mostrando como se faz. (Entrevistado 2)

Todo os que passam aqui pela Usina seja ele prestador de serviço, se é contratado para passar uma semana ou o próprio colaborador tem que passar por um treinamento. Hoje tem essa preocupação de fazer com que você, realmente, ao entrar na empresa já tenha algumas informações e se adeque à cultura da organização. (Coordenador de Gestão Ambiental) 
A usina utiliza mecanismos de conscientização ambiental para efetivar sua administração da sustentabilidade ambiental. Um destes fatos são as palestras de conscientização e a "Semana de Meio Ambiente", realizada anualmente, onde os funcionários e comunidade recebem a visita de palestrantes externos. " hoje temos o auditório cheio de funcionários nas palestras da Semana de Meio Ambiente. Isso nem sempre foi assim, mas hoje as pessoas sabem da importância deste fato na empresa." (Coordenador de Gestão Ambiental)

O Gerente Agrícola destaca que há uma disseminação da preocupação ambiental que envolve desde a alta direção aos outros funcionários do campo, onde o tema tem grande importância. De acordo com as respostas apresentadas pode-se inferir que a cultura da usina considera a variável ambiental. Esse fato é importante, pois apenas treinamentos não reduzem os riscos de danos ao meio ambiente, os funcionários devem ter consciência da importância da preservação do meio ambiente.

As assertivas, quadro 6, possibilitaram evidenciar que a organização, tem preocupação com as demandas provenientes dos clientes, assim como utiliza as ações de sustentabilidade ambiental para promover seus produtos. Esse fato tem relevância como um dos pontos que o coordenador de gestão ambiental, destaca para a adoção da administração da sustentabilidade ambiental na organização.

Quadro 6 - Gestão de Marketing (imagem, produto e informações mercadológicas)

\begin{tabular}{|c|c|c|c|c|c|c|c|}
\hline ASSERTIVA & CENÁRIO 1 & CENÁRIO 5 & 1 & 2 & 3 & 4 & 5 \\
\hline $\begin{array}{l}\text { A competitividade da empresa se } \\
\text { baseia na qualidade de seus } \\
\text { produtos e a organização tem } \\
\text { conseguido comunicar } \\
\text { eficientemente essa qualidade ao } \\
\text { consumidor final. }\end{array}$ & $\begin{array}{l}\text { A boa qualidade não interfere na } \\
\text { competitividade da empresa e o } \\
\text { consumidor não tem informações } \\
\text { sobre qualidade do produto, devido } \\
\text { ao fato de não existir mecanismos } \\
\text { que ressaltem a qualidade do } \\
\text { produto. (ex.: propagandas) }\end{array}$ & $\begin{array}{l}\text { A boa qualidade interfere } \\
\text { na competitividade da } \\
\text { empresa e há propagandas } \\
\text { que ressaltam as qualidades } \\
\text { do produto para os clientes }\end{array}$ & & & 1 & 4 & 7 \\
\hline $\begin{array}{l}\text { Os produtos entregues estão de } \\
\text { acordo com padrão de qualidade } \\
\text { requerido pelos clientes. }\end{array}$ & $\begin{array}{l}\text { O cliente não tem interação com a } \\
\text { empresa e não há mecanismos que } \\
\text { visem avaliar a satisfação do } \\
\text { cliente. }\end{array}$ & $\begin{array}{l}\text { A qualidade é percebida } \\
\text { pelo cliente, tendo em vista } \\
\text { que há total satisfação. }\end{array}$ & & & & 5 & 7 \\
\hline $\begin{array}{l}\text { A empresa possui informações } \\
\text { do mercado e da organização, tal } \\
\text { que a programação seja realizada } \\
\text { com segurança e flexibilidade }\end{array}$ & $\begin{array}{l}\text { Não há canais onde as informações } \\
\text { do mercado sejam captadas para } \\
\text { que ocorram mudanças no sistema } \\
\text { produtivo. }\end{array}$ & \begin{tabular}{llr} 
há canais & \multicolumn{2}{c}{ onde } \\
informações do mercado \\
são captadas para que & seja \\
gerada mudanças no no & nistema produtivo.
\end{tabular} & & 1 & & 7 & 4 \\
\hline $\begin{array}{lr}\text { A gestão ambiental vem } \\
\text { proporcionando } & \text { vantagens } \\
\text { competitivas à } & \text { imagem } \\
\text { institucional da empresa }\end{array}$ & $\begin{array}{l}\text { Não há associação entre a imagem } \\
\text { institucional da organização com } \\
\text { práticas de preservação da } \\
\text { natureza. }\end{array}$ & $\begin{array}{l}\text { Há uma total associação } \\
\text { entre a } \\
\text { institucional da organização } \\
\text { com práticas de preservação } \\
\text { da natureza }\end{array}$ & & & & 1 & 11 \\
\hline 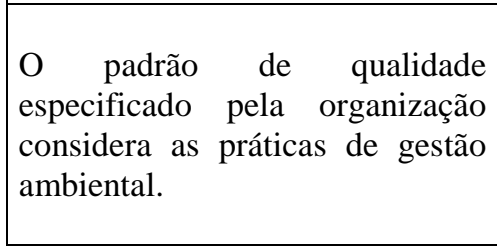 & \begin{tabular}{lllr} 
Durante o & \multicolumn{2}{c}{ processo } & de \\
especificação do produto & a \\
organização não considera & a \\
variável meio ambiente &
\end{tabular} & $\begin{array}{l}\text { A organização, } r \text { ao } \\
\text { especificar os requisitos } \\
\text { para a produção de um } \\
\text { determinador produto, } \\
\text { sempre considera a variável } \\
\text { meio ambiente. }\end{array}$ & & & & 4 & 8 \\
\hline
\end{tabular}

Além das vantagens mercadológicas que os produtos com qualidade ambiental promovem, com a abertura de novos mercados, há outras vantagens. Outro benefício que a organização tem, por meio da administração da sustentabilidade ambiental nas suas atividades é um melhor 
relacionamento com os órgãos de fiscalização ambiental e a comunidade residente no entorno da usina.

Além disso, há a exploração da imagem comercial das certificações e dos prêmios conquistados que fazem referência a temática ambiental. As assertivas do quadro 7 possibilitaram verificar que há consideração da questão ambiental para definição do planejamento da produção. Isso pode ser percebido pelo fato de que a administração da sustentabilidade ambiental provoca uma reestruturação na maneira de exercer suas atividades.

Quadro 7 - Gestão da Produção

\begin{tabular}{|c|c|c|c|c|c|c|c|}
\hline ASSERTIVA & CENÁRIO 1 & CENÁRIO 5 & 1 & 2 & 3 & 4 & 5 \\
\hline $\begin{array}{l}\text { A Gestão Ambiental influencia } \\
\text { nos aspectos da programação da } \\
\text { produção quando há tendência de } \\
\text { danos ambientais. }\end{array}$ & $\begin{array}{c}\text { Ao ser definida a programação da } \\
\text { produção não considera a variável } \\
\text { ambiental }\end{array}$ & $\begin{array}{c}\text { Ao ser definida a } \\
\text { programação da produção } \\
\text { sempre considera a variável } \\
\text { ambiental }\end{array}$ & & & & 6 & 6 \\
\hline $\begin{array}{l}\text { A disposição das máquinas, no } \\
\text { sistema produtivo, facilitam as } \\
\text { práticas de gestão ambiental }\end{array}$ & $\begin{array}{l}\text { A definição do layout, do sistema } \\
\text { produtivo, não considera a variável } \\
\text { gestão ambiental para ser } \\
\text { formulado }\end{array}$ & \begin{tabular}{llcr} 
Há consideração & dos \\
aspectos & da & gestão \\
ambiental para a & definição \\
de qual layout & irá ser \\
utilizado no no & \multicolumn{2}{c}{ sistema } \\
produtivo. & & \multicolumn{2}{l}{} \\
\end{tabular} & & 1 & 2 & 4 & 5 \\
\hline $\begin{array}{l}\text { A empresa está adequadamente } \\
\text { estruturada para um rigoroso } \\
\text { controle dos resíduos. }\end{array}$ & $\begin{array}{l}\text { A organização não possui nenhum } \\
\text { mecanismo que registre e controle } \\
\text { os resíduos produzidos. }\end{array}$ & $\begin{array}{l}\text { A organização possui } \\
\text { mecanismos que registre e } \\
\text { controle totalmente todos os } \\
\text { resíduos produzidos. }\end{array}$ & & & 1 & 5 & 6 \\
\hline $\begin{array}{l}\text { A gestão ambiental interfere nos } \\
\text { fluxos produtivos, por meio de } \\
\text { ações que visam reduzir: } \\
\text { desperdícios, refugos e possíveis } \\
\text { poluentes. }\end{array}$ & $\begin{array}{c}\text { As práticas de gestão ambiental } \\
\text { prejudicam os processos/fluxos } \\
\text { produtivos. }\end{array}$ & $\begin{array}{l}\text { As práticas de gestão } \\
\text { ambiental melhoram os } \\
\text { fluxos produtivos. }\end{array}$ & & 1 & 1 & 3 & 7 \\
\hline $\begin{array}{l}\text { O planejamento produtivo } \\
\text { prioriza a produção de produtos } \\
\text { que minimizem a geração de } \\
\text { resíduos e impactos danosos ao } \\
\text { meio ambiente. }\end{array}$ & $\begin{array}{c}\text { Não há consideração de variável } \\
\text { meio ambiente durante o } \\
\text { planejamento da produção }\end{array}$ & $\begin{array}{c}\text { Há consideração da } \\
\text { variável meio ambiente } \\
\text { durante o planejamento da } \\
\text { produção }\end{array}$ & & & 1 & 4 & 7 \\
\hline $\begin{array}{l}\text { É feito com periodicidade a } \\
\text { manutenção preventiva dos } \\
\text { equipamentos. }\end{array}$ & $\begin{array}{l}\text { Não existe manutenção periódica } \\
\text { dos equipamentos. Eles acontecem } \\
\text { somente quando ocorre uma falta. }\end{array}$ & $\begin{array}{c}\text { Há manutenção periódica } \\
\text { dos equipamentos. }\end{array}$ & & & & 2 & 10 \\
\hline
\end{tabular}

Porém, ainda há entraves para uma melhor reestrutura do setor industrial no que se refere a adequações que a administração da sustentabilidade ambiental solicita. De acordo com o entrevistado 5: "Nossa área industrial é antiga e esse fato dificulta as adaptações do setor produtivo. Fato que não ocorre com as nossas filiais em Minas Gerais, que possuem uma planta nova e já é adaptada a realidade da gestão ambiental”.

Na usina, uma das atribuições do setor de meio ambiente é a gestão dos resíduos gerados. Para cada tipo de resíduo a usina possui uma ação especifica, buscando reutilizar, como também proceder com a destinação adequada destes resíduos. No caso dos resíduos sólidos a empresa possui um sistema de coleta seletiva, que possibilita uma melhor organização e destinação dos resíduos gerados. Quanto a outros resíduos como o bagaço e a torta, estes possuem outra forma de destinação. Estes são reaproveitados, o primeiro na co-geração de energia, o segundo é destinado a fertilização do solo. 
Os resíduos líquidos, por sua vez, também são reaproveitados. A vinhaça é utilizada na fertirrigação da área agrícola da usina. Essa ação possibilita reduzir custos produtivos, como também, reduzir impacto nos corpos hidrográficos, que além de não receberem esse resíduo, não perdem tanto volume de água, pois não se faz necessário a captação de água em regiões que recebem esse resíduo.

O maior problema, destacado nas entrevistas e que ainda não foi solucionado pela organização é a questão das queimadas. Contudo, há por parte da usina um sistema que busca desenvolver controle sobre os resíduos gerados e a organização obtém benefícios econômicos com tais ações, como no caso da vinhaça e do bagaço da cana.

Esse fato é percebido com a gestão dos resíduos que é realizada na organização, onde os mesmos servem de fertilizantes, no caso da vinhaça e da torta-de-filtro a serem utilizados na área agrícola. Outro fato que evidencia isso é a utilização do bagaço para a co-geração de energia, onde a usina substitui a compra de energia elétrica, pela que é produzida em suas dependências. Isso acaba por gerar auto-suficiência energética.

\section{CONSIDERAÇÕES FINAIS}

O presente trabalho buscou realizar uma investigação e discussão sobre a administração da sustentabilidade ambiental em uma organização do setor sucroenergético. A pesquisa focou o processo de internalização da questão ambiental, assim como, a nova dinâmica que se desenvolveu a partir da inserção da sustentabilidade ambiental no sistema organizacional da usina.

Pode-se perceber que ao desenvolver a temática ambiental em seu sistema, a organização tem alterações em diversas áreas internas, como: gestão de pessoas, em que há uma demanda para ações de treinamento e conscientização sobre as novas adequações. Além desta área tem-se, também, a do sistema produtivo ou gestão da produção em que adaptações são realizadas para reduzir os impactos ambientais.

É fato que o processo de internalização da sustentabilidade ambiental, no setor sucroenergético, não é unânime dentre os produtores, pois ainda existem muitos problemas ambientais desencadeados no setor. A própria organização analisada, mesmo desenvolvendo ações de sustentabilidade ambiental, ainda gera danos ao ambiente natural. Entretanto, modificações são sentidas, tendo em vista, a nova imagem que o setor se propõe a desenvolver.

A discussão teórica proposta teve como base o trabalho de dois autores, Habermas e Luhmann. O uso de ambos serviu para entender como se desenvolve o processo de pressão para que o setor sucroenergético aderisse, mesmo parcialmente, a preocupação com a sustentabilidade ambiental da sua atividade. Essa parte é fundamental, no trabalho, pois de acordo com a tese habermasiana, antes do desenvolvimento da sociedade, em sistemas funcionalmente diferenciados, havia um entendimento que era compartilhado entre as pessoas. Esse local é denominado por ele de "mundo da vida".

Contudo, no desenvolvimento da sociedade, principalmente a ocidental, houve um processo em que essas ações comunicativas de compartilhamento foram substituídas pela codificação. Para entender essa guinada usa-se a teoria de sistemas de Luhmann. O mesmo considera que em decorrência da complexidade existente no "mundo social", os sistemas surgem como uma forma de reduzir tal complexidade e possibilitar a operacionalização de determinadas funcionalidades. Diante deste fato os sistemas emergem como sendo mecanismos "auto-fechados" que interagem com outros sistemas, por meio da seleção comunicativa, baseada em códigos. Isso acaba por desencadear uma "pseudo compreensão" da realidade existente no mundo fora dos sistemas. 
O "auto-fechamento", para Habermas (1992), é a raiz das patologias da sociedade moderna. Pois, segundo o autor, a perda da pluralidade comunicativa acaba por parcelar a realidade e o entendimento sobre a mesma. Tal fato incapacita os sistemas de compreenderem a dinâmica ocorrida no mundo que os circunscreve. O uso desta crítica habermasiana nos possibilitou entendermos que a "pseudo compreensão" foi a chave para a problemática ambiental que emergiu como ponto de discussão na sociedade do século XX.

A evidenciação dos problemas ambientais surge não no sistema, pois o mesmo é incapaz de detectá-lo, mas sim nos espaços que estão fora deles e que resgatam o que ocorre no mundo da vida. Estes espaços são denominados, por Habermas (1997) como esfera pública. Neste ambiente, as pessoas interagem de forma comunicativa, resgatando o compartilhamento de entendimentos sobre determinados assuntos. O autor destaca que na esfera pública demandas das esferas privadas ou íntimas dos participantes, são postas para o debate plural e diante disto os demais participantes passam a entender e discutir sobre o fato. As discussões acabam por desencadear uma opinião pública sobre o tema debatido.

Como forma de denunciar os problemas desencadeados pela racionalidade econômica e, principalmente, para evidenciar os problemas ambientais, o movimento ambientalista desenvolve uma "esfera pública ambiental". Esta por sua vez, passa a debater, publicamente, os problemas ambientais vividos pela sociedade moderna.

Dos debates concretizados na esfera pública ambiental emerge um entendimento de que a interação entre sistema e ambiente externo ou entorno, deve ser repensada. Diante deste fato surge a ideia de sustentabilidade, ou seja, dar sustentação ao mecanismo de intercâmbio sistema/ambiente externo, porém, considerando variáveis até então não consideradas. Para o caso da problemática ambiental, tem-se a sustentabilidade ambiental que é o mecanismo adotado para que o sistema, no momento de sua interação considere as limitações existentes no ambiente natural.

A dinâmica desenvolvida pelos debates da esfera pública ambiental, não se restringem a sociedade civil, a mesma passa a invadir outros campos, como o debate político sobre o meio ambiente. O debate político sobre a problemática ambiental e as iniciativas que dela decorrem, como a criação de leis e de órgãos ambientais mostram que há uma internalização do que é debatido na esfera pública, para o interior do sistema. Contudo, a internalização não se limita ao campo político, outros sistemas também acabam por, utilizando um termo luhmanniano, "irritar-se". Esses são o sistema mercado e, consequentemente, o sistema organização empresarial.

O sistema mercado passa, por meio das críticas geradas na esfera pública, internalizar as preocupações com o meio ambiente. Esse fato desencadeia em demandas para as organizações. Estas, por sua vez, devem adotar alterações internas visando reduzir os impactos ambientais derivados das suas atividades. Para reduzir os impactos as organizações adotam a administração da sustentabilidade ambiental, como forma de equilibrar a interação entre organização (sistema) e ambiente natural.

O instrumental teórico utilizado neste trabalho permite sugerirmos que no campo organizacional o uso da teoria habermasiana, baseada em uma comunicação discursiva, possibilita ampliar o campo interpretativo existente de um mundo externo a organização (sistema). Seu uso pode vim a desencadear uma maior aproximação entre a organização e os fatos que ocorrem no mundo da vida e desta forma reduzir as "irritações" provenientes do ambiente/entorno.

A crítica de Habermas ao fechamento dos sistemas possibilita repensar a forma como ocorre a interação entre a organização empresarial e o seu entorno, que é altamente dinâmico. Isso reflete na incapacidade do funcionalismo sistêmico de interagir com a dinâmica, desencadeando, em muitas vezes, prejuízos para a própria organização. A dinâmica pode ser percebida, pelas alterações 
que ocorrem, tanto no mercado, que passa a demandar uma qualidade ambiental para o produto, quanto o Estado que passa a desenvolver legislações específicas sobre a temática ambiental.

Diante deste fato é que a administração da sustentabilidade ambiental, a ser desenvolvida no campo organizacional, se torna ainda mais importante. Essa importância não se limita apenas ao setor sucroenergético, mazss também aos demais setores que necessitam modificar sua postura, pois como percebemos o "auto-fechamento" sistêmico, acaba por limitar a percepção dos riscos que a ação entrópica desencadeia, para a própria manutenção das atividades produtivas.

\section{REFERENCIAS}

ARAÚJO, R. M. S. de. Análise da gestão ambiental em empresas agroindustriais de usinas de açúcar e álcool no Mato Grosso do Sul. 2001. 122p. (Dissertação de mestrado em Administração). Universidade Federal do Rio Grande do Sul, Porto Alegre, 2001.

CMUMAD (Comissão Mundial sobre Meio Ambiente e Desenvolvimento). Nosso futuro comum. $2^{\mathrm{a}}$ Rio de Janeiro: FGV, 1991.

EGRI, C. P.; PINFIELD, L. T. Organizations and the Biosphere: Ecologies and environments. In:CLEGG, Stewart; HARDY, Cynthia; NORD, Walter R. Handbook of organization studies. London: Sage, 1997.

EPELBAUM, M. A influência da gestão ambiental na competitividade e no sucesso empresarial. Dissertação de Mestrado em Engenharia da Produção. São Paulo: Escola Politécnica da Universidade de São Paulo, 2004.

ESTEVES, J. P. Niklas Luhmann: uma apresentação. texto publicado em 1993. Disponível em: http://www.bocc.ubi.pt/pag/esteves-pissarra-luhmann.pdf. Acesso em: 22 jan. 2009.

FEDOZZI, L. A nova teoria de sistemas de Niklas Luhmann: uma leitura introdutória. In: NEVES, C. E. B.; SAMIOS, E. M. B. Niklas Luhmann: a nova teoria dos sistemas. Porto Alegre: UFRGS, 1997.

FREYRE, G. Nordeste; aspecto da influencia da canna sobre a vida e a paizagem do nordeste do Brasil.. Rio de Janeiro: J. Olympio, 1937.

Brasilia, 1963

Casa-grande \& senzala. 12. ed. bras. ; 13. ed. em lingua portuguesa. [Brasilia]: Ed. Universidade de

FURTADO, C. Formação economica do Brasil. 33. ed São Paulo Nacional 2004.

HABERMAS, J. O pensamento pós-metafísico. Rio de Janeiro: Tempo Brasileiro, 1990.

Teoría de la acción comunicativa, II: crítica de la razón funcionalista. Madrid: Taurus, 1992.

Direito e democracia: entre faticidade e validade, v. II. Rio de Janeiro: Tempo Brasileiro, 1997.

HOLANDA, S. B. de. Raízes do Brasil. [26. ed.] São Paulo: Cia. das Letras, 1995.

KUNZLER, C. de M. Teoria dos sistemas de Niklas Luhmann. Estudos de Sociologia, Araraquara, v. 16, n. , p.123136, 2004.

LEIS, H. R. A modernidade insustentável: as críticas do ambientalismo à sociedade contemporânea. Florianopolis: Edufsc, 1999.

LUHMANN, N. Social systems. Stanford: Stanford University Press, 1995.

Organización y decisión. Autopoieses, acción y entedimiento comunicativo. México: Anthropos, 1997. MAIMON, D. Passaporte verde: gestão ambiental e competitividade. Rio de Janeiro: Qualitymark, 1996.

MCCORMICK, J. Rumo ao paraíso: a história do movimento ambientalista. Rio de Janeiro: Relume-Dumará, 1992.

NASCIMENTO, L. F.; LEMOS, A. D. da C. e MELLO, M. C. de. Gestão socioambiental estratégica. Porto Alegre: Bookman, 2008.

NEVES, C. E. B.; NEVES, F. M.. O que há de complexo no mundo complexo? Niklas Luhmann e a Teoria dos Sistemas Sociais. Sociologias, Porto Alegre, n. 15, p.182-207, jan-jun, 2006.

PORTER, M. e VAN DER LINDE, C. Green and Competitive: Ending the Stalemate, Harvard Business Review, v.73, n.5, pp. 120-134, 1995. 
PORTILHO, F. Consumo verde, consumo sustentável e a ambientalização dos consumidores. In: Encontro nacional da ANPPAS, 2., 2004, Indaiatuba. Anais... . Indaiatuba: Anppas, 2004. p. 1 - 21. Disponível em: <http://www.anppas.org.br>. Acesso em: 19 mar. 2008.

SEIDL, D.; BECKER, K. H. Organizations as distinction generating and processing systemas: Niklas Luhmann's contribution to organizacion studies.Organization, London, v. 1, n. 13, p.9-35, abr. 2006 a.

SEIDL, D.; BECKER, K. H. (Ed.). Niklas Luhmann and Organization Studies. Denamark: Copenhagen Business School Press, 2006b.

SACHS, I Caminhos para o desenvolvimento sustentável. Rio de Janeiro: Garamond, 2000.

Rumo à Ecosocioeconomia. Teoria e prático do desenvolvimento. São Paulo: Cortez, 2007.

SANCHES, C. S. Gestão ambiental proativa. RAE - v.40, n.1. p. 76-87. jan/mar, 2000.

VIOLA, E. J.. A multidimensionalidade da globalização, as novas forças sociais transnacionais e seu impacto na política ambiental do Brasil (1989-1995). In: FERREIRA, Leila da Costa; VIOLA, Eduardo J.. Incertezas da sustentabilidade na globalização. Campinas: Unicamp, 1996.

YOUNG, C. E. F.; LUSTOSA, M. C. J. Meio ambiente e competitividade na indústria brasileira. 2001. Disponível em: www.ie.ufrj.br/gema. Acesso em: 30 de abril, 2006. 